\title{
Effect of Bio, Organic and Chemical Fertilization on Growth, Productivity and Oil Consituents of Caraway (Carum carvi, L.). El-Tarawy, M. A. ${ }^{1}$; M. A. Hegazi ${ }^{1}$ and Eman Mahmoud ${ }^{2}$ \\ ${ }^{1}$ Hort. Dept., Fac. of Agric., Kafrelsheikh Univ., Kafr El- Sheikh, Egypt. \\ ${ }^{2}$ Expert in the Ministry of Justice - Gharbia Governorate - Egypt.
}

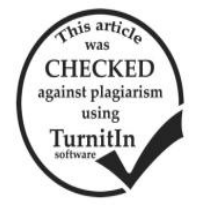

\section{ABSTRACT}

A field trial was carried out during 2013/2014 and 2014/2015 seasons at the Experimental Farm of Faculty of Agriculture, Kafr El- Sheikh University to study the effect of bio, organic and chemical fertilization on growth, seed yield, essential oil and its main components as well as some chemical constituents (N, P and K) of Caraway plants. Compost was applied at the rate of $10 \mathrm{~m}^{3}$ /fed., during soil preparation. NPK, active dry yeast, seaweed extract, amino acids free and triamin plus were added as folair spray. The common agricultural practices i.e. watering, weed control, etc. were done whenever plants needed and the obtained results could be summarized as follows: Compost in combinations with active dry yeast or amino acids free or triamin plus significantly enhanced both Caraway plant growth and productivity of seeds or essential seed oil contents. GCM (gas chromatography) analyses for oil components shown the presence of o-guaiene, 2,6- dihydroxyacetophenone, hydrocinnamic acid, $\alpha$ - gurjunene, chamigrene and caryophyllene in the seeds volatile oil. All treatments didn't succeed in improving the main components of the volatile oil (carvone) but the plants fertilized with seaweed extract treatment gave high means of most component of the volatile oil.

Keywords: Caraway, fertilization, vegetative growth, seed yield, essential oil.

\section{INTRODUCTION}

Nowadays, a great tendency for cultivation of both medicinal and aromatic plants has been shown in Egypt in order to cover the increasing demands for the local industries and as a good source of hard currency.

Caraway (Carum carvi, L.) is one of the important aromatic plants belongs to Apiaceae family. The dried fruit (commonly called seeds) contain approximately 1-6\% essential oil, with carvone and limonene as the principal components. Caraway seeds contain also lipids (13-21\%), nitrogen compounds (25-35\%), fiber (13-19\%) and water (9-13\%) Kocourkova et al., (1999). Caraway seed is wellknown used in meat, food and distillery industries due to its pleasant flavor and intense taste. Its antibacterial and fungicidal properties are important in pharmaceutical applications and also in human and veterinary medicine Sedlakova et al., (1998). Caraway is considered a feedstuff that increases milk production, improves taste and digestibility and reduces flatulence of cattle.

Caraway essential oil is used as a natural inhibitor of sprouting, mainly in stored potatoes as mentioned by Kleinkopf et al., (2003). It has also antiseptic, pain sedative, antispasmodic, depletive and antioxidant properties as reported by Dyduch et al., (2006) and Sembratowicz and Czech, (2005).

Recently, unusual efforts are used to minimize the amounts of chemical fertilizers practical to medicinal and aromatic plants to obtain safe production besides reducing production costs and environmental pollution without reduction of yield.

Many researchers have reported the nutritional requirements of macronutrients for some plants. They revealed that NPK fertilizers had important physiological and biochemical functions on structure of photosynthetic pigments, metabolism of carbohydrates and protein. These effects were noticed with significant increase in vegetative growth, seed yield and essential oil content of the different plant species. The nutritional requirements of NPK for Apiaceae family, in this concern, Nofal et al., (2001), Kenawy (2010) and Sabra (2014) on Ammi visnaga L., and Milica et al., (2015) on Caraway, anise and coriander.
Composts are organic products containing living cells of different types of microorganisms that have an ability to convert nutritionally important elements from unavailable to available form through biological processes and are known to help with expansion of the root system and better seed germination (Vessey, 2003; Ebrahimi et al., 2010). Furthermore, compost benefits water absorption and retention by the soil, reducing erosion and run-off and help blinding agricultural chemicals, and defending ground water from contamination (Hussein et al., 2006).

Active dry yeast is a natural safety bio-fertilizer causes various primitive effects on plants. It is considered as a natural source of cytokinins which stimulates cell division and enlargement as well as the synthesis of protein, nucleic acid and B-vitamin, as stated by Amer (2004) on Phaseolus vulgaris L. It also releases CO2 which reproduced in improving net photosynthesis, as indicated by Kutzman and Fell, (2005). Abdelaziz et al., (2007) reported that plants of Rosmarinus officinalis, L. treated with a mixture of compost and microorganisms showed significant increases in total N, P and carbohydrate contents.

Seaweed (Laminaria saccharina, Fucus vesiculosus and Ascophyllum nodosum) extracts contain alginic acid and its salts were shown as being the main organic compounds accountable for reducing the effect of the metals with mustard plants. It is suggested that alginic acid competes with the plants by ion-exchange for the metals in the extract (Blunden, et al 2006).

Amino acids can play wide roles in plants including acting as regulatory and signaling molecules. Amino acids also affect synthesis and activity of some enzymes and gene expression (Rai, 2002). Many studies have reported that foliar application of amino acids caused an increase in the growth and development of plants. Omer et al. (2013) reported that foliar spray with amino acids improved the growth and chemical composition of chamomile plant.

Therefore, the objective of this study was to substitute chemical fertilizers by some natural materials to achieve safe Caraway production. 


\section{MATERIALS AND METHODS}

A field experiment was conducted at the Experimental Farm, Faculty of Agriculture at Kfrelsheikh Univ., during 2013/2014 and 2014/2015 seasons, to study the effect of bio-organic, chemical fertilization and their mixtures on growth, seed yield, essential oil productivity and some chemical constituents of Carum carvi, L. plants.

Caraway seeds were supplied from the National Research Center, Dokki, Egypt and sown in a clay soil for two seasons on November $15^{\text {th }}$ in plots $2 \times 2 \mathrm{~m}$ with four rows at $50 \mathrm{~cm}$ apart in each plot and $50 \mathrm{~cm}$ between the seed hills within the row. One month later, the hills were thinned at two plants/ hill as every plot contained 16 hills / plot and replicated 3 times in a completely randomized block design.

Mechanical and chemical analyses of the experimental soils and compost analysis are presented in Tables (A, B and C).

Table A. Mechanical analysis of the experimental soil:

\begin{tabular}{lccc}
\hline Parameters & \multirow{2}{*}{ Unit } & \multicolumn{2}{c}{ Season } \\
\cline { 3 - 4 } Depth 0-20 cm & & $\mathbf{2 0 1 3 / 2 0 1 4}$ & $\mathbf{2 0 1 4 / 2 0 1 5}$ \\
\hline Coarse sand & $\%$ & 14.24 & 13.48 \\
Silt & $\%$ & 36.65 & 48.53 \\
Clay & $\%$ & 50.11 & 52.11 \\
Textural class & - & Clayey loam & Clayey loam \\
\hline
\end{tabular}

Table B. Chemical analysis of the experimental soil:

\begin{tabular}{|c|c|c|c|c|c|c|c|c|c|c|}
\hline \multirow{2}{*}{ Seasons } & \multirow{2}{*}{ pH } & \multirow{2}{*}{$\begin{array}{c}\text { ECe } \\
(d s \backslash m)\end{array}$} & \multicolumn{4}{|c|}{ Soluble cations ( meq / l ) } & \multicolumn{4}{|c|}{ Soluble Anions ( $\mathrm{meq} / \mathrm{S}$ ) } \\
\hline & & & $\mathrm{Ca}^{2+}$ & $\mathbf{M g}^{2+}$ & $\mathbf{K}^{+}$ & $\mathrm{Na}^{+}$ & $\mathrm{Co}_{3}{ }^{2}$ & $\mathrm{Hco}^{3-}$ & CL - & $\mathrm{So}_{4}{ }^{2-}$ \\
\hline 14 & 8.10 & 6.16 & 20.84 & 9.91 & 0.28 & 30.26 & - & 3.00 & 50.20 & 11.09 \\
\hline $2014 / 2015$ & 8.10 & 7.01 & 19.15 & 17.65 & 0.24 & 40.32 & - & 2.25 & 48.80 & 26.31 \\
\hline
\end{tabular}

Table C. Chemical analysis of the used compost (average of both seasons).

\begin{tabular}{lccccccccccc}
\hline $\mathbf{N}$ & $\mathbf{P}$ & $\mathbf{K}$ & $\mathbf{C a}$ & $\mathbf{M g}$ & $\mathbf{F e}$ & $\mathbf{Z n}$ & $\mathbf{M n}$ & $\mathbf{O . M}$ & \multirow{2}{*}{ C/N ratio } & pH & \multirow{2}{*}{ EC (ds/m) } \\
\hline & & $\mathbf{( \% )}$ & & & & $\mathbf{( p p m )}$ & & $\mathbf{( \% )}$ & & \multirow{2}{*}{ (\%) } \\
\hline 1.47 & 0.95 & 1.185 & 4.63 & 0.89 & 4309.35 & 215.4 & 461 & 37.1 & $15.45: 1$ & 7.55 & 5.35 \\
\hline
\end{tabular}

Fertilization treatments were conducted as follows: Organic fertilizer (compost) was applied at the rate of $10 \mathrm{~m}^{3} /$ fed., during soil preparation on November of both seasons. Foliar applications were four equal doses at 30, 45, 60 and 75 days after sowing as follow: 1-NPK (19:19:19) was added at the rate of $1 \mathrm{~g} / \mathrm{l}$.

2-Active dry yeast (Saccharomyces cerevisiae) was added at the rate of $5 \mathrm{~g}$ per one liter of water (Ahmed, 1998).

3 -Seaweed extract was added at the rate of $2 \mathrm{ml}$ from the commercial product algreen per one liter of water (recommended dose).

4-Amino acids free were added monthly at the rate of $2 \mathrm{~g}$ from the commercial product called amino total (40\% total amino acids) per one liter of water (recommended dose).

5-Amino acids free + triamin plus (added at the rate of $5 \mathrm{ml}$ from the commercial product).

6-Compost + active dry yeast + seaweed extract.

7-Compost + active dry yeast + amino acids free.

8-Compost + active dry yeast + amino acids free + triamin plus.

9-Compost + active dry yeast.

10- Control (untreated plants).

The common agricultural practices i.e. watering, weed control, etc. were done whenever plants needed.

Data recorded.

Complete blooming was occurred in March 1st of both seasons as data of plant height, branchs number/plant and umbel number/plant were recorded. At the end of the experiment (after seeds ripening), data of umbels weight/ plant, weight of 100 seeds, seed yield/ plant and fed; harvest index (the ratio of seed yield / plant to the total above ground according to Ullah et al., 2006), herb fresh and dry weight/plant were recorded. Also, chlorophyll a and b were determined in fresh leaves according to Moran (1982). Total nitrogen was determined in dried samples of plant aerial parts (A.O.A.C., 2000). Phosphorus was determined colorimetrically according to Murphy \& Riley (1962). Potassium $(\mathrm{K}+)$ was determined using Sherwood 410 flame photometer. (Chapman, and pratt. 1961).

Extraction of the essential oil:

The seeds of carawy were hydrodistilled in a Clevenger's type apparatus for $6 \mathrm{~h}$. Yellow colored oil, with characteristic odor and sharp taste, was obtained. It was dried over anhydrous sodium sulphate to eliminate traces of moisture and stored in a refrigerator in the dark at $4 \mathrm{oC}$ until use. Essential oil percentage, yield/ plant and per fed were calculated (European Pharmacopoeia procedure, 1983).

GC-MS analysis of essential oil:

The chemical analysis of carawy essential oil was undertaken by Gas Chromatography-Mass Spectroscopy (GC-MS) techniques in National Research Center, Giza, Egypt according to the methods outlined by Singh et al. (2006).

\section{Statistical analysis.}

The obtained data in both seasons of the study were exposed to analysis of variance as a complete randomized design with three replicates Duncan's multiple range test was performed for comparing means (Duncan, 1955).

\section{RESULTS AND DISCUSSION}

Effect of the used treatments on growth, seeds and oil production and oil consituents of caraway (Carum carvi, L.):

a-Effect on growth characters:

Data presented in Table (1) showed that, there were a significant increases in plant height and branch and umbel numers of caraway plant over control in both seasons (Table, 1). NPK, active dry yeast (ADY) treatments gave the tallest plants, wherease, the treatment of $\mathrm{C}+\mathrm{ADY}+$ AAF+TAP excedded all other treatments in both branch and umbel numbers beside plant dry weight. The other treatments recorded an intermediate values in both seasons. 
Table 1. Effect of bio, organic and chemical fertilization treatments on some vegetative growth characters and plant dy weight of Carum carvi, L. during the two seasons of 2013/2014 and 2014/2015.

\begin{tabular}{lcccccccc}
\hline \multirow{2}{*}{ Treatments } & \multicolumn{2}{c}{ Plant height $\mathbf{( c m})$} & \multicolumn{2}{c}{ Branch No. /plant } & \multicolumn{2}{c}{ Umbels No./plant } & \multicolumn{2}{c}{ D.W./plant (g) } \\
\cline { 2 - 8 } & $\mathbf{1}^{\text {st }} \mathbf{S}$ & $\mathbf{2}^{\text {nd }} \mathbf{S}$ & $\mathbf{1}^{\text {st }} \mathbf{S}$ & $\mathbf{2}^{\text {nd }} \mathbf{S}$ & $\mathbf{1}^{\text {st }} \mathbf{S}$ & $\mathbf{2}^{\text {nd }} \mathbf{S}$ & $\mathbf{1}^{\text {st }} \mathbf{S}$ & $\mathbf{2}^{\text {nd }} \mathbf{S}$ \\
\hline NPK (19:19:19) & $102.2 \mathrm{a}$ & $100.7 \mathrm{a}$ & $9 \mathrm{bc}$ & $9 \mathrm{bc}$ & $19 \mathrm{ab}$ & $20 \mathrm{ab}$ & $59.92 \mathrm{~d}$ & $51.66 \mathrm{ef}$ \\
Active dry yeast (ADY) & $101.3 \mathrm{a}$ & $100.0 \mathrm{a}$ & $9 \mathrm{bc}$ & $10 \mathrm{bc}$ & $17 \mathrm{bc}$ & $15 \mathrm{bc}$ & $73.91 \mathrm{bc}$ & $65.65 \mathrm{bc}$ \\
Seaweed extract (SE) & $87.20 \mathrm{bc}$ & $86.92 \mathrm{c}$ & $8 \mathrm{~cd}$ & $8 \mathrm{~cd}$ & $14 \mathrm{~cd}$ & $14 \mathrm{~cd}$ & $46.08 \mathrm{ef}$ & $37.82 \mathrm{fg}$ \\
Amino acids free (AAF) & $99.87 \mathrm{ab}$ & $96.25 \mathrm{ab}$ & $8 \mathrm{~cd}$ & $8 \mathrm{~cd}$ & $14 \mathrm{~cd}$ & $13 \mathrm{~cd}$ & $77.43 \mathrm{~b}$ & $69.17 \mathrm{bc}$ \\
AAF + triamin plus (TAP) & $91.87 \mathrm{bc}$ & $92.75 \mathrm{bc}$ & $7 \mathrm{~cd}$ & $7 \mathrm{~cd}$ & $12 \mathrm{~cd}$ & $12 \mathrm{~cd}$ & $41.08 \mathrm{fg}$ & $32.82 \mathrm{~g}$ \\
Compost (C) + ADY+SE & $95.67 \mathrm{abc}$ & $92.92 \mathrm{bc}$ & $9 \mathrm{bc}$ & $10 \mathrm{bc}$ & $15 \mathrm{bc}$ & $15 \mathrm{bc}$ & $63.42 \mathrm{~cd}$ & $55.16 \mathrm{de}$ \\
C + ADY+ AAF & $85.87 \mathrm{c}$ & $86.08 \mathrm{c}$ & $9 \mathrm{bc}$ & $7 \mathrm{~cd}$ & $16 \mathrm{bc}$ & $11 \mathrm{~cd}$ & $56.81 \mathrm{de}$ & $48.55 \mathrm{de}$ \\
C + ADY+ AAF+TAP & $98.73 \mathrm{abc}$ & $92.67 \mathrm{bc}$ & $18 \mathrm{a}$ & $16 \mathrm{a}$ & $25 \mathrm{a}$ & $20 \mathrm{a}$ & $88.91 \mathrm{a}$ & $80.65 \mathrm{a}$ \\
C + ADY & $93.60 \mathrm{bc}$ & $95.25 \mathrm{c}$ & $11 \mathrm{~b}$ & $12 \mathrm{~b}$ & $14 \mathrm{~cd}$ & $14 \mathrm{~cd}$ & $41.66 \mathrm{fg}$ & $33.40 \mathrm{~g}$ \\
Control & $42.00 \mathrm{~d}$ & $66.25 \mathrm{~d}$ & $6 \mathrm{~d}$ & $7 \mathrm{~cd}$ & $9 \mathrm{~d}$ & $12 \mathrm{~cd}$ & $34.00 \mathrm{~g}$ & $25.74 \mathrm{~g}$ \\
\hline
\end{tabular}

Means in the same column followed by the same letter are not significantly different according to $\mathrm{DMRT}$ at $(\mathrm{P}>\mathrm{0.05})$. $\mathrm{S}=\mathbf{s e a s o n}$

These results are in covenant with those of Kandeel (2004) on Basil , El-Sayed et al., (2002) on spearmint and majoran, Niakan et al., (2004) on Mentha piperita; Mostafa (2006) on chamomile; El-Maadawy (2007) on Amaranthus sp, Gomaa and youssef (2007) on fennel and Badran et al., (2007) on cumin.

b- Effect on seed measurements:

It was noticed from presented data in Table (2) that, highest seeds yield per plant and per fedan were recorded when the treatments of compost + active dry yeast + amino acids free + triamin plus $(\mathrm{C}+\mathrm{ADY}+\mathrm{AAF}+\mathrm{TAP})$ and amino acids free (AAF) were used followed by compost + active dry yeast + seaweed extract $(\mathrm{C}+\mathrm{ADY}+\mathrm{SE})$ applied without significancy among them in both seasons.

The tratment of compost + active dry yeast + amino acids free + triamin plus $(\mathrm{C}+\mathrm{ADY}+\mathrm{AAF}+\mathrm{TAP})$ recorded the heaviest 100 seeds at all. Likewise, the treatment of compost + active dry yeast + seaweed extract $(\mathrm{C}+$ $\mathrm{ADY}+\mathrm{SE}$ ) recorded the highest harvest index percentage. This may be due to that amino acids or active dry yeast affect synthesis and activity of some enzymes and gene expression. These results are in harmony with those of Amer (2004) on Phaseolus vulgaris, Blunden, (2006) on black mustard and Omer et al.(2013) on chamomile plants.

Table 2. Effect of of bio, organic and chemical fertilization on fruts (seeds) measurments of Carum carvi, L. during the two seasons of 2013/2014 and 2014/2015.

\begin{tabular}{|c|c|c|c|c|c|c|c|c|}
\hline \multirow[t]{2}{*}{ Treatments } & \multicolumn{2}{|c|}{$\underset{(g)}{\text { Seed yield /plant }}$} & \multicolumn{2}{|c|}{$\begin{array}{c}\text { Seed yield /fed. } \\
\text { (kg) }\end{array}$} & \multicolumn{2}{|c|}{$\begin{array}{l}\text { Weight of } 100 \\
\text { Seeds }(\mathrm{g})\end{array}$} & \multicolumn{2}{|c|}{$\begin{array}{l}\text { Harvest Index } \\
\text { (HI) \% }\end{array}$} \\
\hline & $1^{\text {st }} \mathrm{S}$ & $2^{\text {na }} S$ & $1^{\mathrm{st}} \mathrm{S}$ & $2^{\text {na }} S$ & $1^{\text {st }} \mathrm{S}$ & $2^{\text {na }} S$ & $1^{\text {st }} \mathrm{S}$ & $2^{\text {na }} S$ \\
\hline NPK (19:19:19) & $12.93 \mathrm{c}$ & $11.66 \mathrm{c}$ & $297 \mathrm{c}$ & $268 \mathrm{c}$ & $1.85 \mathrm{~b}$ & $1.98 \mathrm{~b}$ & $21.77 \mathrm{c}$ & $22.83 \mathrm{c}$ \\
\hline Active dry yeast (ADY) & $16.59 \mathrm{bc}$ & $15.32 \mathrm{bc}$ & $382 \mathrm{bc}$ & $352 \mathrm{bc}$ & $1.92 \mathrm{~b}$ & $2.04 \mathrm{a}$ & $22.34 \mathrm{c}$ & $23.20 \mathrm{c}$ \\
\hline Seaweed extract (SE) & $13.16 \mathrm{c}$ & $11.89 \mathrm{c}$ & $303 \mathrm{c}$ & $273 \mathrm{c}$ & $1.50 \mathrm{~d}$ & $1.63 \mathrm{~cd}$ & $28.92 \mathrm{bc}$ & $32.16 \mathrm{~b}$ \\
\hline Amino acids free (AAF) & $23.16 \mathrm{a}$ & $21.89 \mathrm{a}$ & $533 a$ & $503 a$ & $1.59 \mathrm{~cd}$ & $1.72 \mathrm{~cd}$ & $30.03 b$ & $31.81 \mathrm{~b}$ \\
\hline AAF + triamin plus (TAP) & $11.59 \mathrm{c}$ & $10.32 \mathrm{c}$ & $267 \mathrm{c}$ & $237 \mathrm{c}$ & $1.44 \mathrm{~d}$ & $1.57 \mathrm{~cd}$ & $28.19 b c$ & $31.42 b$ \\
\hline Compost (C) + ADY+SE & $21.52 \mathrm{ab}$ & $20.25 \mathrm{ab}$ & $495 \mathrm{ab}$ & $466 a b$ & $1.80 \mathrm{bc}$ & $1.93 \mathrm{~b}$ & $34.08 \mathrm{a}$ & $36.95 \mathrm{a}$ \\
\hline $\mathrm{C}+\mathrm{ADY}+\mathrm{AAF}$ & $13.33 \mathrm{c}$ & $12.06 \mathrm{c}$ & $307 \mathrm{c}$ & $277 \mathrm{c}$ & $1.82 \mathrm{bc}$ & $1.95 \mathrm{~b}$ & $22.93 \mathrm{c}$ & $24.13 \mathrm{c}$ \\
\hline $\mathrm{C}+\mathrm{ADY}+\mathrm{AAF}+\mathrm{TAP}$ & $26.75 \mathrm{a}$ & $25.48 \mathrm{a}$ & $615 \mathrm{a}$ & $586 \mathrm{a}$ & $2.20 \mathrm{a}$ & $2.33 \mathrm{a}$ & $30.02 b c$ & $31.51 \mathrm{bc}$ \\
\hline $\mathrm{C}+\mathrm{ADY}$ & $11.83 \mathrm{c}$ & $10.56 \mathrm{c}$ & $272 \mathrm{c}$ & $243 c$ & $1.47 \mathrm{~d}$ & $1.60 \mathrm{~cd}$ & $28.83 \mathrm{bc}$ & $32.39 b$ \\
\hline Control & $13.66 \mathrm{c}$ & $7.06 \mathrm{c}$ & $314 \mathrm{c}$ & $162 \mathrm{c}$ & $0.95 \mathrm{e}$ & $1.08 \mathrm{~d}$ & $30.02 b c$ & $27.67 \mathrm{c}$ \\
\hline
\end{tabular}

Means in the same column followed by the same letter are not significantly different according to DMRT at $(\mathrm{P}>0.05)$. $\mathrm{S}=\mathbf{s e a s o n}$

c- Effect on content and components of essential oil:

Data presented in Table (3) show that, the treatment of compost + active dry yeast + amino acids free $(\mathrm{C}+$ $\mathrm{ADY}+\mathrm{AAF}$ ) followed by the treatment of amino acids free + triamin plus (AAF + TAP) gave the significantly highest essential oil percentage and yield per plant and per feddan in both seasons as recorded $2.00-2.06,1.6-1.65$ and $36.8-$ 37.95 , followed by $1.87-1.93,1.5-1.54 \mathrm{~b}$ and $34.5-35.42$ in both seasons respectively.

Table 3. Effect of bio, organic and chemical fertilization treatments on essential oil productivity of Carum carvi, L. during the two seasons of 2013/2014 and 2014/2015.

\begin{tabular}{lcccccc}
\hline Treatments & \multicolumn{2}{c}{ Essential oil (\%) } & \multicolumn{2}{c}{ Essential oil yield /plant (ml) } & \multicolumn{2}{c}{ Essential oil yield /fed (l) } \\
\cline { 2 - 7 } & $\mathbf{1}^{\text {st }} \mathbf{S}$ & $\mathbf{2}^{\text {nd }} \mathbf{S}$ & $\mathbf{1}^{\text {st }} \mathbf{S}$ & $\mathbf{2}^{\mathbf{1 n}} \mathbf{S}$ & $\mathbf{1}^{\text {st }} \mathbf{S}$ & $\mathbf{2}^{\mathrm{nd}} \mathbf{S}$ \\
\hline NPK (19:19:19) & $1.70 \mathrm{c}$ & $1.50 \mathrm{~d}$ & $1.4 \mathrm{~d}$ & $1.20 \mathrm{~d}$ & $32.2 \mathrm{c}$ & $27.60 \mathrm{~d}$ \\
Active dry yeast (ADY) & $1.25 \mathrm{e}$ & $1.23 \mathrm{e}$ & $1.0 \mathrm{e}$ & $0.98 \mathrm{e}$ & $23.0 \mathrm{~d}$ & $22.54 \mathrm{e}$ \\
Seaweed extract (SE) & $1.87 \mathrm{~b}$ & $1.68 \mathrm{c}$ & $1.5 \mathrm{~d}$ & $1.34 \mathrm{c}$ & $34.5 \mathrm{c}$ & $30.82 \mathrm{c}$ \\
Amino acids free (AAF) & $1.25 \mathrm{e}$ & $1.38 \mathrm{e}$ & $1.0 \mathrm{e}$ & $1.1 \mathrm{~d}$ & $23.0 \mathrm{~d}$ & $25.30 \mathrm{~d}$ \\
AAF + triamin plus (TAP) & $1.87 \mathrm{~b}$ & $1.93 \mathrm{~b}$ & $1.5 \mathrm{~b}$ & $1.54 \mathrm{~b}$ & $34.5 \mathrm{~b}$ & $35.42 \mathrm{~b}$ \\
Compost (C) ADY+SE & $1.50 \mathrm{~d}$ & $1.65 \mathrm{~d}$ & $1.2 \mathrm{~d}$ & $1.32 \mathrm{~cd}$ & $27.6 \mathrm{~d}$ & $30.36 \mathrm{c}$ \\
C+ ADY+ AAF & $2.00 \mathrm{a}$ & $2.06 \mathrm{a}$ & $1.6 \mathrm{a}$ & $1.65 \mathrm{a}$ & $36.8 \mathrm{a}$ & $37.95 \mathrm{a}$ \\
C+ ADY+ AAF+TAP & $1.50 \mathrm{~d}$ & $1.40 \mathrm{~d}$ & $1.2 \mathrm{~d}$ & $1.12 \mathrm{~d}$ & $27.6 \mathrm{~d}$ & $25.76 \mathrm{~d}$ \\
C + ADY & $1.70 \mathrm{c}$ & $1.53 \mathrm{~d}$ & $1.4 \mathrm{~d}$ & $1.22 \mathrm{~d}$ & $32.2 \mathrm{c}$ & $28.06 \mathrm{~d}$ \\
Control & $1.37 \mathrm{e}$ & $1.23 \mathrm{e}$ & $1.1 \mathrm{e}$ & $0.98 \mathrm{e}$ & $25.3 \mathrm{e}$ & $22.54 \mathrm{e}$ \\
\hline
\end{tabular}

Means in the same column followed by the same letter are not significantly different according to DMRT at $(\mathrm{P}>\mathbf{0 . 0 5})$. $S=$ season

On the contrary, active dry yeast (ADY) and control treatments recorded the absolutely least values without signifant differences in between in both seasons while the other treatments recorded intermediate values in both seasons. These are in agreement with those of (Rai, 2002), 
Kutzman and Fell, (2005) and Blunden, (2006) on black mustard.

As for oil components data presented in Table (4) reveal that, the main constituents of caraway essential oil of plants treated with seaweed extract (SE) was o- guaiene $(6.95 \%)$ followed by hydrocinnamic acid (3.98\%), 2,6dihydroxyacetophenone $(3.9 \%)$ and caryophyllene (3.35\%), other constituents were less than (3\%). However, the main components of essential oil of caraway plants treated with amino acids free + triamin plus (AAF + TAP) was $\alpha$-gurjunene at a relative percent of $5.08 \%$ followed by p-cresol,2,2,- methylenebis (6- tert-butyl) with (3.81\%), o- guaiene (3.59\%), and chamigrene (3.41\%).

The main constituents of essential oil plants treated with compost + active dry yeast + amino acids free $(\mathrm{C}$ $+\mathrm{ADY}+\mathrm{AAF})$ was ơ- guaiene $(7.63 \%)$ followed by caryophyllene (4.79\%), M-cresol, 5-ethyl (3.31\%) and acoradien (3.02) and the other constituents were less than $3 \%$. The main constituents of essential oil plants treated with compost + active dry yeast + amino acids free + triamin plus $(\mathrm{C}+\mathrm{ADY}+\mathrm{AAF}+\mathrm{TAP})$ was o- guaiene (4.84\%) followed by estragole (4.04\%) and $\alpha$ - gurjunene (3.69\%), other constituents were less than $3 \%$.

The main constituents essential oil of control plants was o- guaiene (5.94\%) followed by caryophyllene (5.1\%), acoradien (4.5\%), estragole (3.84\%) and $\alpha$ - gurjunene (3.22\%), other constituents were less than 3\%. Therfore, oguaiene was the main component of all stutdied treatment exept for the treatments of amino acids free + triamin plus (AAF + TAP) as the main constituent was $\alpha$ - gurjunene. Foliar spray with seaweed extract, active dry yeast or amino acids improved plant growth and chemical composition according to Blunden, (2006) on black mustard, Abdelaziz et al., (2007) and Omer et al., 2013.

Table 4. Effect of bio, organic and chemical fertilization treatments on essential oil consituents of Carum carvi, L. during the season of 2014/2015.

\begin{tabular}{|c|c|c|c|c|c|}
\hline $\begin{array}{l}\text { Treatments } \\
\text { Oil consituents }\end{array}$ & 3 & 5 & 7 & 8 & 10 \\
\hline 2,6- dihydroxyacetophenone & 3.90 & 0.89 & 1.59 & 1.38 & $\overline{0.79}$ \\
\hline Hydrocinnamic acid & 3.98 & 1.96 & 2.18 & 1.86 & 1.13 \\
\hline Sinapyl alcohol & 2.80 & 3.11 & 2.35 & 1.84 & 0.93 \\
\hline$\beta$ - ocimene & 2.70 & 2.52 & 1.48 & 2.09 & 1.51 \\
\hline Carveol & 1.89 & 3.08 & 1.32 & 1.69 & 0.79 \\
\hline m - cresol ,5 - ethyl- & 3.05 & 1.47 & 3.31 & 1.92 & 2.10 \\
\hline Caryophyllene & 3.35 & 2.78 & 4.79 & 4.30 & 5.10 \\
\hline Terpinolene & 1.89 & 2.33 & 1.81 & 2.47 & 1.65 \\
\hline Acoradien & 2.29 & 1.31 & 3.02 & 0.72 & 4.50 \\
\hline Phellandral & 2.21 & 0.49 & 1.41 & 0.88 & 0.70 \\
\hline ơ - guaiene & 6.95 & 3.59 & 7.63 & 4.84 & 5.94 \\
\hline 1- pirilladegyde & 2.31 & ----- & 1.11 & 1.20 & 1.38 \\
\hline 3-tgujen - 2- one & 1.44 & 0.84 & 1.48 & 1.06 & 1.45 \\
\hline Estragole & 2.15 & 1.19 & 0.94 & 4.04 & 3.84 \\
\hline Longifolene & 2.54 & 1.82 & 0.45 & 1.86 & 2.02 \\
\hline Chamigrene & 2.62 & 3.41 & 1.70 & 2.54 & 2.21 \\
\hline Resveratol & 2.63 & 3.00 & 2.19 & 2.59 & 2.18 \\
\hline Ledene & 2.75 & 3.28 & 2.25 & 2.17 & 2.56 \\
\hline$\alpha$ - gurjunene & 2.72 & 5.08 & 2.52 & 3.69 & 3.22 \\
\hline p- cresol ,2,2,- methylenebis & 3.20 & 3.81 & 0.44 & 2.14 & 2.87 \\
\hline
\end{tabular}

d-Effect on some chemical consituents.

Caraway plants applied with amino acids free recorded the highest percentage of both nitrogen and phosphorus (3.2 and 3.39, 0.47 and $0.48 \%$, respectively), followed by that apllied with compost + active dry yeast (C + ADY) as recorded 3.3 and $3.42 \%$ in the first season. Active dry yeast (ADY) gave the absolutely highest potassium means (4.78 and 4.53 in both seasons respectively). These results are coordination with the findings of Kandeel (2004) on basil, Niakan et al., (2004) on Mentha sp, El-Maadawy (2007) on Amaranthus tricolor, and Gomaa and Youssef (2007) on fennel.

Table 5. Effect of bio, organic and chemical fertilization treatments on on some chemical consituents of Carum carvi, L. plants during 2013/2014 and 2014/2015 seasons.

\begin{tabular}{|c|c|c|c|c|c|}
\hline \multirow{2}{*}{ Treatments } & N (\%) & \multicolumn{2}{|c|}{ P (\%) } & \multicolumn{2}{|c|}{ K (\%) } \\
\hline & $1^{\text {st }} \mathrm{S} 2$ & & $\mathbf{S}$ & $1^{\text {st }} \mathrm{S}$ & $2^{n}$ \\
\hline 19:19) & 2.462 .58 & 0.21 & 0.22 & 2.10 & 2.2 \\
\hline Y yeest (ADY) & $2.53 \quad 2.14$ & 0.15 & 0.13 & $4.78 \mathrm{a}$ & 4.5 \\
\hline & $2.73 \quad 2.84$ & 0.25 & 0.26 & 2.33 & 3. \\
\hline & $3.2 \mathrm{a} 3.39 \mathrm{a}$ & $0.47 \mathrm{a}$ & $0.48 \mathrm{a}$ & 2.95 & 2.34 \\
\hline & $2.53 \quad 2.65$ & 0.15 & 0.16 & 3.3 & 4.25 \\
\hline & $3.00 \mathrm{~b} 3.04$ & 0.20 & 0.21 & 1.96 & 2.1 \\
\hline & $2.87 \quad 2.87$ & $0.42 \mathrm{a}$ & $0.43 b$ & $3.67 \mathrm{~b}$ & 3.0 \\
\hline & $2.82 .92 \mathrm{~b}$ & 0.13 & 0.14 & 3.41 & 3.75 \\
\hline & $3.3 \mathrm{a} 3.42$ & $0.28 b$ & 0.29 & 2.44 & 2.6 \\
\hline ontrol & $1.8 \quad 1.89$ & 0.10 & 0.11 & 1.8 & 1.68 \\
\hline \multicolumn{6}{|c|}{$\begin{array}{l}\text { Means in the same column followed by the same letter are not } \\
\text { significantly different according to DMRT at }(P>0.05) . S=\text { season }\end{array}$} \\
\hline CONC & \multicolumn{4}{|c|}{ CONCLUSION AND } & \\
\hline
\end{tabular}

Compost in combination with seaweed extrac (added at the rate of $2 \mathrm{ml}$ from the commercial product algreen per one liter of water (recommended dose)), active dry yeast (added at the rate of $5 \mathrm{~g}$ per one liter of water) or amino acids (added monthly at the rate of $2 \mathrm{~g}$ from the commercial product called amino total (40\% total amino acids) per one liter of water (recommended dose)), can be a safe substitute to the chemical fertilizers for medicinal plants. It can minimize the amounts of chemical fertilizers besides reducing production costs and environmental pollution without reduction of yield. It can recommended that, compost in combinations with active dry yeast or amino acids free or triamin plus or seaweed extract for obtaining the best growth and productivity Caraway plants.

\section{REFERENCES}

Abdel Aziz, M,R. Pokluda and M. Abdel Wahab (2007). Influence of compost, microorganisms and N.P.K. fertilizer upon gowth, chemical, composition and essential oil production of Rosmarinus officinalis, $\mathrm{L}$. Nat. Bot. Hort. Agrobot Cloi., 1(1): 86 - 90.

Ahmed, T. E. (1998). Influence of spraying active dry yeast on growth and volatile oil content of Majorana hortensis plants. Proc. $2^{\text {nd }}$ Conf. of Ornamental Hort. Fac. Agric. Suez Canal Univ. Ismailia., 24-26 Oct., Egypt

A.O.A.C. (1980). Official Methods of Analysis,12Th Ed. Association of Official Analysis Chemists :Washington, D.C., U.S.A.

Badran, F.S.; M.K. Aly; E.A. Hassan and S.G. Shalatet (2007). Effect of organic and biofertilization treatments on cumin plants. Pros. Third Conf. of Sustain. Agric. Develop. Fac. Agric., Fayoum Univ., 12-14 Nov., 371-380. 
Blunden, G.; S.B. Challen and D.L. Woods (2006). Seaweed extracts as fertilizers. Journal of the Science of Food and Agriculture, 19 (6): 289 - 293.

Champman, H.D. and Pratt (1961). Methods of Analysis of Soil, Plant and Water. Univ. Calf.

Duncan, D. B. (1955). Multiple range and multiple F-test Biometrics, II: 42.

Dyduch J., Najda A., Brzozowski N. 2006. [Growth and chemical content of caraway (Carum carvi L.) in the first year of cultivation]. Folia Hortic. sup. 2006/1: 108- 112. [in Polish with English summary]

Ebrahimi, A.; P. Moaveni,and H. Aliabadi Farahani (2010). Effects of planting dates and compost on mucilage variations in borage (Borago officinalis L.) under different chemical fertilization systems. International Journal for Biotechnology and Molecular Biology Research, 1(5): 58 -61.

El-Maadawy, E.I. (2007). Response of summer annual flowering plants to chemical, organic and biofertilization treatments 1- Joseph's coat (Amaranthus tricolor, L.) plants. J. Product. \& Dev., 12 (1): 133152.

Gomaa, A.O. and A.S.M. Youssef (2007). Influence of chemical, organic and bio-fertilizer application on growth and productivity of lovage plant (Levisticum officinale, Koch). Egypt. J. of Appl. Sci., 22 (IIB): 492-520.

Kandeel, Y.M.R. (2004). Effect of bio, organic and chemical fertilization on growth, essential oil productivity and chemical composition of Ocimum basilicum, L. plant. Annals of Agric. Sci., Moshtohor, 42(3): 1253-1270.

Kleinkopf GE, NA Oberg, N Olsen. 2003. Sprout inhibition in storage: currentstats, new chemistries and natural compounds. Am. J. Potato Res. 80:317 327.

Kocourková b., s edláková j., h olubová v. (1999): Morfologické a kvalitativní znaky registrovaných odrùd. In: Proc. Conf. Caraway in present plant production. MZLU Brno, 34-41.

Kurtzman, C.P., Fell, J.W., Robert, V., and Boekhout, T. 2005. Methods to identify yeasts. In: Yeasts in Food, T. Boekhout and V. Robert (eds.), chap. 3. pp. 69121. B. Behr's Verlag GMBH \& Co., Hamburg, Germany.

Milica G. A.; Ž. K. Dolijanović and S.I. Oljača (2015). Effect of organic and mineral fertilizers on essential oil content in caraway, anise and coriander fruits, Acta Sci. Pol., Hortorum Cultus 14(1), 95-103 University of Belgrade ISSN 1644-0692.
Moran, R., 1982. Formulae for determination of chlorophyllous pigments extracted with $\mathrm{N}, \mathrm{N}-$ dimethyl formamide. Plant Physiol. 69, 1376 - 1381.

Mostafa, H.S. (2006). Effect of some bio-fertilizers compared with chemical fertilizers on growth, yield and active constituents of chamomile plant (Matricaria chamomilla). M. Sc. Thesis, Fac. of Agric., Benha Univ., Egypt.

Murphy J.P. Riley J.A, Modified single solution method for the determination of phosphate in natural waters. Analytica Chimica Acta Volume 27, 1962, Pages 3136.

Niakan, M.; R.A. Khavarynejad and M.B. Rezaee (2004). Effects of different rates of NPK fertilizer on the leaf fresh weight, dry weight, leaf area and oil content of Mentha piperita, L. Iranian Journal of Medicinal and Aromatic Plants Research, 20 (2): 131-148.

Nofal, E.S.; Kandeel, Y.R.; Menesi, F.A.; Reda, K.A.; Taher,M. and Zaki, Z.T. (2001). Effect of some cultural practices on growth and chemical composition of some medicinal plants in northern Sinai. 1- Ammi visnaga, L. proc. $5^{\text {th }}$ Arab. Hort. Conf., Ismailia, Egypt, March 24-28,2001, (51-60)

Omer, E.A.; H.A.H. Said -Al Ahl; A.G. El Gendy; Kh. A. Shaban and M.S. Hussein (2013): Effect of amino acids application on production, volatile oil and chemical composition of chamomile cultivated in saline soil at Sinai. J. Appl. Sci. Res., 9(4): 3006 3021.

Rai, V.K. (2002). Role of amino acids in plant responses to stresses. Biologia Plantarum, 45(4): 481- 487.

Sedláková j., kubáò v., Holubová v., kocourková b. (1998): Stanovení silic v kmínu. In: Proc. Conf. Analysis of organic compounds in environment. 2-Theta, K. Lhotka:120-126 (ISBN 80-902432-6-6).

Sembratowicz I., Czech A. 2005. [Natural antioxidants in the food]. Post. Nauk Roln. 1: 75-88. [in Polish with English summary]

Singh, G.; S. Maurya; M. de Lampasona and S. Catalan (2006). Chemical constituents, antifungal and antioxidative potential of Foeniculum vulgare volatile oil and its acetone extract. Food Control, 17:745-752.

Ullah, I.M.; U.R. Rahman and Y. Zafar (2006). Genotypic variation for drought tolerance in cotton (Gossypium hirsutum L.):seed cotton yield responses. Pak. J. Bot., 38(5):1679-1687.

Vessey, J.K. (2003). Plant growth promoting rhizobacteria as biofertilizers. Plant Soil., 255: 571 - 586.

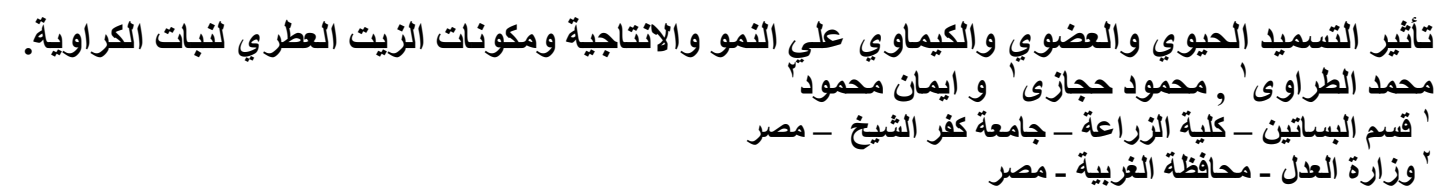

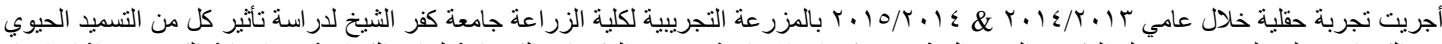

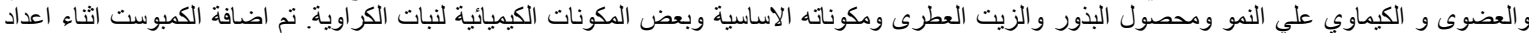

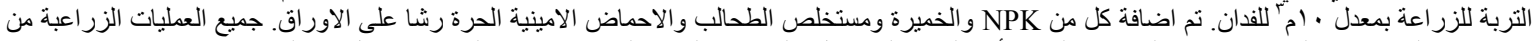

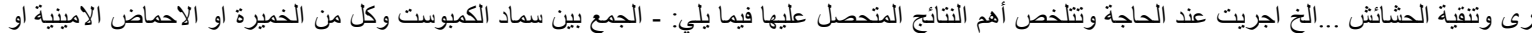

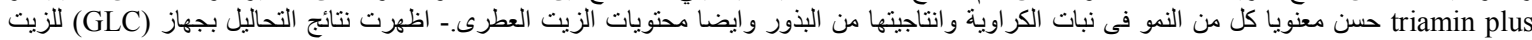

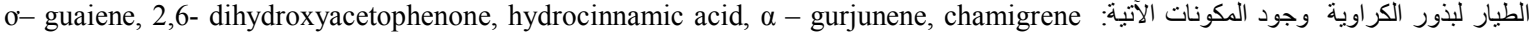
and caryophyllene

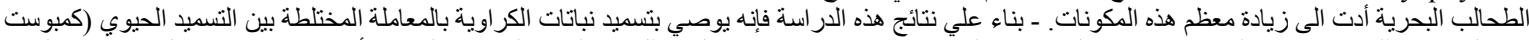

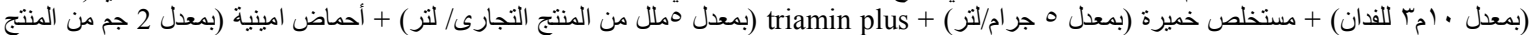

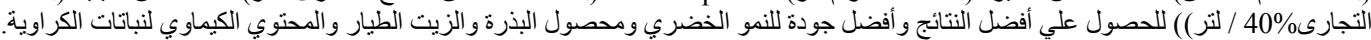

